\title{
CZY NIETYPOWE GROBY ODKRYWANE NA WCZESNOŚREDNIOWIECZNYCH STANOWISKaCH ARCheOlogiczNYCH Z TERENU POLSKI TO POCHÓWKI WAMPIRÓW?
}

\author{
Anna Kubicka, aannakubicka@wp.pl \\ Uniwersytet Łódzki \\ ul. Narutowicza 65, 90-131 Łódź
}

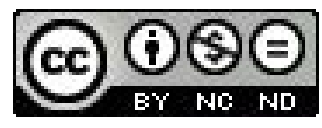

\begin{abstract}
Abstrakt
Niniejszy artykuł poruszać będzie zagadnienia związane z obrzędowością czasów wczesnego średniowiecza. Autorka skupi się na omówieniu nietypowych pochówków wczesnośredniowiecznych lokalizowanych na terenie Polski, które często w literaturze występują pod nazwą " pochówków antywampirycznych”. Przeanalizowane zostaną zarówno praktyki dotyczące jamy grobowej jak i bezpośrednio ciała zmarłego. W dalszej części referatu podjęte będą również próby wyjaśnienia, z jakich przyczyn część z pochówków odnajdowanych na cmentarzyskach datowanych na X-XIII w. różni się od powszechnie przyjętej normy. Autorka postara się także udzielić odpowiedzi na pytanie, czy rzeczywiście są to miejsca spoczynku istot, które tradycja ludowa nazywa wampirami lub strzygami.

Słowa kluczowe: archeologia, śmierć, pochówki, wczesne średniowiecze, wampiryzm
\end{abstract}

Whether the unusual graves discovered on early medieval archaeological sites in Poland are burials of vampires?

\section{Abstract}

This article describes issues related to the early medieval rituals. The author focuses on discussing untypical early medieval burials located in Poland. These burials often appear in literature under the name of „anti vampiric burials". I will analyze both the practices for the grave pit and directly to the body of the deceased. Finally, I will try to explain why some of the burials discovered in the graveyards of the tenth to the thirteenth century are different from the generally accepted norm. and whether they are indeed the burial place of beings that folk tradition called vampires.

Key words : archaeology, death, burial, early Middle Ages, vampirism

System wierzeń ludzi żyjących we wczesnym średniowieczu stanowi wyjątkowo ciekawy temat badawczy, jednak z racji nikłości przekazów pisanych oraz pozostałości materialnych jest bardzo trudny do zidentyfikowania i rekonstruowania. Pochówki, które archeolodzy odkrywają na cmentarzyskach datowanych na okres od X do XIII w. to jedne z niewielu uchwytnych śladów wierzeń społeczności tamtych czasów. Wyjątkowo ważne staje się więc dokładne i wnikliwe obserwowanie i interpretowanie możliwych do zarejestrowania elementów obrządku pogrzebowego.

Czym jednak w ogóle jest obrządek pogrzebowy i jakimi cechami charakteryzował się on w okresie wczesnego średniowiecza? Według Marii Miśkiewicz „obrządek pogrzebowy to zespół zjawisk, reprezentujący określone wierzenia poszczególnych grup ludzkich w zakresie zagadnienia śmierci, które uzewnętrzniają się w specyficznych zabiegach prowadzących do ostatecznego odseparowania zmarłego od ogółu pozostałych przy życiu. Wyrazem archeologicznym takiego działania są ślady istnienia zespołu reguł stosowanych konsekwentnie podczas czynności chowania zmarłych"1. Badacze wczesnego średniowiecza zaobserwowali, iż charakterystyczną formą pochówku szkieletowego, omawianego okresu, było ułożenie zmarłego na wznak, w pozycji wyprostowanej, z rękami wzdłuż ciała. Jamy grobowe orientowano na osi wschód - zachód, z głową skierowaną na wschód lub na zachód².

1 M. Miśkiewicz, Wczesnośredniowieczny obrzadek pogrzebowy na plaskich cmentarzyskach szkieletowych w Polsce, „Materiały Wczesnośredniowieczne" 1969, T. 6, s. 244.

2 A. Koperkiewicz, Święci czy przeklęci? Kilka refleksji o anomaliach w pochówkach wczesnośredniowiecznych, [w:] K. Skóra, T. Kurasińnki (red.), Wymiary inności. Nietypowe zjawiska w obrzędowości pogrzebowej od pradziejów po czasy nowożytne, Łódź 2010, s. 65. 
Podczas prac archeologicznych prowadzonych na wczesnośredniowiecznych stanowiskach sepulkralnych, odkrywane są również, choć stosunkowo rzadko, groby wyraźnie różniące się od ustalonego i powszechnie stosowanego wzoru. Warto zaznaczyć, iż pochówki z różnych przyczyn identyfikowane jako nietypowe, występują na cmentarzyskach, także tych przykościelnych, na terenie całej Polski. Groby takie odkryto między innymi w Adolfinie, Kałdusie, Cedyni, Dębczynie, Wolinie, Złotej Pińczowskiej, Niemczy czy Sandomierzu, największą ich ilość zarejestrowano na Pomorzu oraz w Małopolsce. Mogiły różniły się między sobą rodzajem oraz ilością zastosowanych zabiegów uznawanych za nietypowe. Badacze od dłuższego czasu starają się odkryć choćby prawdopodobne przyczyny wystąienia takich anomalii. Według wielu z nich, czynności wykonywane podczas chowania zmarłego, odmienne od powszechnie akceptowanych, będące wykluczeniem ze zwykłych obrzędów pogrzebowych, dotyczyły osobników, których śmierć budziła zastrzeżenia społeczeństwa, była nagła i nietypowa lub przedwczesna ${ }^{3}$, a także tych, którzy już za życia wykraczali, ze względu na swój wygląd lub zachowanie, poza przyjęte kanony - np. czarownice lub osoby kalekie. Wierzenia ludowe podaja, iż tacy zmarli stawali się upiorami - wampirami', którzy powracali do świata żywych, aby szkodzić. Z racji tego, iż według ówczesnych społeczności wszystkie zabiegi podczas pochówku tego typu osób wykonywano w celach ochronnych, zabezpieczających, określa sięje często jako antywampiryczne ${ }^{5}$. Miały one za zadanie uniemożliwić wydostanie się domniemanego upiora z mogiły. Postępowanie takie służyło do uspokojenia ludności, z którą za życia związany był potencjalnie niebezpieczny dla otoczenia zmarly.

Zabiegi atypowe identyfikowalne archeologicznie podzielić można na dwie kategorie -praktyki dotyczące jamy grobowej i praktyki wykonywane na samym pochówku'.

Grupa praktyk wykonywanych bezpośrednio na zwłokach:

- odcięcie głowy, ułożenie jej między nogami lub poza grobem,

- wkładanie ostrych przedmiotów tkwiących między kośćmi szkieletu,

- $\quad$ ułożenie zwłok w pozycji skurczonej, zwykle na boku (tzw. pozycja embrionalna), układ szkieletu sugerujący krępowanie,

- wciśnięcie między szczęki kamienia lub grudy gliny,

- $\quad$ szkielet zwrócony twarzą do ziemi, pozycja „na brzuchu”,

- ciało przygniecione kamieniami.

Grupa praktyk wykonywanych na pochówku:

- grób usytuowany na peryferiach lub poza cmentarzem,

- nietypowa orientacja względem stron świata,

- brak wyposażenia, ewentualnie występowanie przedmiotów "magicznych",

- $\quad$ ślady wtórnego otwarcia grobu lub zwęglenia?.

W celu uniknięcia ryzyka błędnej interpretacji charakteru danego obiektu, stosuje się kryterium ilościowe. Aby móc choćby wstępnie określić dany pochówek jako antywampiryczny, wymagane jest współwystapienie zespołu minimum trzech wyżej wymienionych cech określanych jako nietypowe ${ }^{8}$. Sceptyczni badacze dostrzegają bowiem wiele możliwości zaistnienia szeregu zaburzeń, możliwych do wythumaczenia w racjonalny sposób9 .

Ślady dekapitacji rozpatrywać można jako bezpośrednią przyczynę zgonu, zaistniałą podczas wojen lub najazdów. Podkreślić jednak należy, iż w tych przypadkach ścięta głowa zwykle wkładana była do grobu na właściwym miejscu,

3 Często społeczności średniowieczne uważały, iż zmarłe dzieci, najczęściej nieochrzczone lub z wyraźnymi deformacjami ciała, nie mogąc zaznać radości i przyjemności życia dorosłych, miały po śmierci wracać jako demony i straszyć pozostałych przy życiu.

4 W średniowieczu nie znano słowa ,wampir”, używano głównie określen , „trzyga” lub „upiór”.

5 Ł. M. Stanaszek, Znaczenie cech morfofunkcjonalnych osobnika dla sposobu jego pochówku na przykladzie tzw. pochówków antywampirycznych [w:] W. Dzieduszycki, J. Wrzesińnki (red.), Środowisko pośmiertne człowieka, Poznań 2007, s. 283.

6 A. Falis, Zabiegi antywampiryczne w grobach dziecięcych we wczesnośredniowiecznej Polsce, [w:] A. Buko, W. Duczko (red.), Przez granice czasu. Księga Jubileuszowa poświęcona Prof. J. Gąssowskiemu, Pułtusk 2008, s. 109.

7 L. Gardeła, Gryźz ziemię! Pochówki na brzuchu we wczesnośredniowiecznej Polsce w perspektywie porównawczej, „Pomnik Dawnego Prawa” 2011, z. 16, s. 38 .

8 P. Żydok, Wczesnośredniowieczne pochówki antywampiryczne, [w:]. Z. Kobyliński (red.), Hereditatem cognoscere. Studia i szkice dedykowane Prof. Marii Miśkiewicz, Warszawa 2004, s. 45.

9 Tamże, s. 44. 
wraz z resztą ciała ${ }^{10}$. Dodatkowo, w okresie średniowiecza wykonanie wyroku manifestowano często przez wystawienie na widok publiczny odciętej głowy lub przybicie jej w widocznym miejscu dużymi gwoździami. Praktyka ta mogłaby tłumaczyć znajdowane niekiedy otwory w czaszkach. Również dokładne obserwacje kontekstu archeologicznego umożliwiają rozwikłanie przyczyn pozornie nietypowych pozycji ciała zmarłego, takich jak przesuniecie czy nieobecność czaszki ${ }^{11}$. Występowanie przy szczątkach ostrych przedmiotów pozwala wnioskować, iż, przynajmniej w niektórych przypadkach, mogą one być narzędziem, które było bezpośrednią przyczyną śmierci oraz którego nie wyjęto z ciała i tak dostało się ono do grobu ${ }^{12}$. Natomiast spalenizna obserwowana wyłącznie w określonych miejscach szkieletu mogła być pozostałością po oczyszczaniu zwłok, kiedy osoba zmarła w okolicznościach epidemii lub gdy bezpośrednią przyczyną śmierci był pożarr ${ }^{13}$. Ponadto niejednokrotnie po wykonaniu wyroku próbowano unicestwić zwłoki skazanego, ćwiartując je bądź też poddając niszczącemu działaniu płomieni ${ }^{14}$. Nietypową zaś, skurczoną pozycję ciała, spowodować mógł gwałtowny zgon, po którym ciało zastygło w nienaturalnym ułożeniu ${ }^{15}$. Ponadto zaobserwować można podobieństwo typowej i powtarzalnej pozycji nietypowego pochówku, to jest skurczonego ciała, skrzyżowanych nóg i rąk umieszczonych pod broda, do często przedstawianego w ikonografii wyobrażenia chrześcijan w pozycji interpretowanej jako wizerunek smutnych, ubogich, skromnych. Badając cmentarzyska, najczęściejjuż chrześcijańskie, gdzie o odpowiednie sprawowanie obrzędów pogrzebowych dbał kler, należałoby rozpatrzyć początkowo możliwość wystąpienia szczególnego rodzaju gestów pokutnych, mieszczących się w chrześcijańskiej wizji eschatologicznej ${ }^{16}$. Niepewne są bowiem poglądy, sugerujące, iż tzw. zabiegi antywampiryczne wywodzą się z wierzeń tradycyjnych, ponieważ pojawiły się one wraz z rozpowszechnieniem inhumacji lub dopiero od tego momentu są możliwe do zaobserwowania. Przypuszczalnie, gdyby miały one ściśle pogański charakter, byłyby zwalczane przez władze kościelną ${ }^{17}$. Nie należy zapominać również, iż wielu możnych i władców takich jak Pepin Krótki, Ryszard II czy papież Sylwester II życzyło sobie być pochowanymi w nietypowy sposób, między innymi na brzuchu lub z odciętymi kończynami. Chcieli przez to zamanifestować pokore, chęć czynienia pokuty i prośbę o odpuszczenie win $^{18}$.

Prawdopodobieństwo, iż anomalie zaobserwowane w pochówkach wynikają z magicznych zabiegów przeciw wampirom zwiększa się, kiedy ciało, nawet wyprostowane, pochowane jest na boku lub na brzuchu. Aczkolwiek ułożenie zmarłego twarzą do ziemi wiązane jest także z mogiłami skazańców, dodatkowo pohańbionych taką formą pochówku lub z grobami osobników zmarłych na zarazę, których wrzucano do jamy grobowej, nie zawsze dbając o ich właściwe ułożenie $^{19}$

Istnieją jednakże pewne zjawiska nietypowe, których badacze nie umieją wytłumaczyć inaczej, jak tylko celową działalnością członków społeczności, którzy odpowiedzialni byli za pogrzebanie danego osobnika. Do praktyk takich należą wtórne wkopy wykonane w celu przeprowadzenia dodatkowych zabiegów, takich jak zalanie ciała wapnem, przygniecenie go dużymi głazami czy umieszczenie $w$ ustach grudki gliny, monety lub kamienia ${ }^{20}$. Zatkanie ust zmarłego uniemożliwić miało jego zemstę, zwłaszcza zapobiec rzucaniu uroków przez osoby podejrzewane o zajmowanie się czarami. Dodatkowo, jako tzw. „,obol zmarłych”, moneta stanowiła formę zapłaty za usługi dla duszy w zaświatach. Choć w większości mogił określanych jako nietypowe brak jest jakiegokolwiek wyposażenia, to niekiedy odkrywane są pewnego rodzaju przedmioty, postrzegane przez żałobników jako magiczne. Były to wspomniane wyżej monety, a także jajka, grzechotki oraz, choć rzadziej i nieco później, kaptorgi na amulety, kły dzikich zwierząt czy belemnity²1 . Źródła etnologiczne wska-

10 M. Garas, Pochówki atypowe na cmentarzyskach zachodniopomorskich w dobie chrystianizacji, [w:] K. Skóra, T. Kurasiński (red.), Wymiary inności. Nietypowe zjawiska w obrzędowości pogrzebowej od pradziejów po czasy nowożytne, Łódź 2010, s. 59.

11 A. Koperkiewicz, Święci czy przeklęci..., dz. cyt., s. 69.

12 Ł. M. Stanaszek, Praktyki antywampiryczne w XI wieku stosowane na terenie cmentarzyska szkieletowego na Wzgórzu Świętojakubskim w Sandomie$r z u$, ,Biuletyn Antropologiczny” 1998, t. 2, s. 21.

13 A. Sikorski, Atypowe groby szkieletowe z cmentarzyska w Dębczynie (stan. 53), woj. zachodniopomorskie, [w:] J. Wrzesiński (red.), Czarownice, Funeralia Lednickie, t.2, Wrocław-Sobótka 2000, s. 136.

14 D. Wojtucki, Pochówki skazańców na Śląsku i Łużycach w świetle nowożytnych źródet historycznych, „Śląskie Sprawozdania Archeologiczne” 2007, t. 48 , s. 325 .

15 H. Malinowska-Lazarczyk, Badania wykopaliskowe na cmentarzysku w Cedyni w latach 1976-1985, „Materiały Zachodniopomorskie” 1985, t. 31, s. 85.

16 A. Koperkiewicz, Święci czy przeklęci..., dz. cyt., s. 75.

17 Tamże, s. 71.

18 Tamże, s. 75.

19 H. Zoll-Adamikowa, Wczesnośredniowieczne cmentarzyska szkieletowe Matopolski, cz. II-Analiza, Wrocław 1971, s. 52.

20 Tamże.

21 M. Miśkiewicz, Wczesnośredniowieczny obrządek..., dz. cyt., s. 267.

OGRODY NAUK I SZTUK NR 2014 (4) 
zują, iż skorupki jajek postrzegano jako rodzaj zamknięcia i izolacji między światem żywych i umarlych. Wierzono, że umieszczone w grobie zapobiegać będą powrotowi zmarłego na ziemię. Także grzechotki, biorąc pod uwagę ich ciężar, kształt zbliżony do jajka oraz występujący na nich ornament analogiczny do pisanek, uznać można za przedmioty pełniące funkcje obrzędowo - magiczne, nie zaś wyłącznie zabawki dla dzieci²2.

\section{Podsumowanie}

Podsumowując: być może to wyjątkowa pobożność czy chęć odpokutowania grzechów, nie zaś wiara w ludowe strzygi, mogły wpływać chociażby na część z pochówków określanych mianem antywampirycznych ${ }^{23}$. Ponadto odstępstwa od ogólnie przyjętych zwyczajów pogrzebowych mogą być świadectwem rozbudowanego systemu kar średniowiecznych. Pochówek odmienny był dodatkowym pohańbieniem, ukaraniem złoczyńcy po jego śmierci. Brak pojedynczych kończyn, np. dłoni mógł być skutkiem okaleczenia za drobniejsze przewinienia ${ }^{24}$. Następnie warto byłoby skupić się na racjonalnych powodach występujących odmienności, takich jak działalność zwierząt, obsunięcie się ziemi, wkopanie się w jamę grobową bądź też inne procesy podepozycyjne. Na samym końcu zaś rozważać należy wątki upiorów i wierzeń ludowych ${ }^{25}$. Ogromnym bowiem błędem i nadinterpretacją jest uznawanie wszystkich pochówków, w których odkryto ślady nietypowych zabiegów, jako grobów antywampirycznych. Konieczne wydają się indywidualne badania i refleksja nad każdym z odkrytych przypadków. Umożliwi to wyciagnięcie obiektywnych i pewniejszych wniosków wyjaśniających przyczyny pochowania danego zmarłego w sposób odmienny od powszechnie obowiązującego.

\section{Bibliografia}

[1] Falis A., Zabiegi antywampiryczne wo grobach dziecięcych we wczesnośredniowiecznej Polsce, [w:] Buko A., Duczko W. (red.), Przez granice czasu. Księga Jubileuszowa poświęcona Prof. J. Gąssowskiemu, Pułtusk 2008.

[2] Garas M., Pochówki atypowe na cmentarzyskach zachodniopomorskich w dobie chrystianizacii, [w:] Skóra K., Kurasiński T. (red.), Wymiary inności. Nietypowe zjawiska wobrzędowości pogrzebowej od pradziejów po czasy nowożytne, nr 56, Łódź 2010.

[3] Gardeła L., Gryźz ziemię! Pochówki na brzuchu we wczesnośredniowiecznej Polsce w perspektywie porównawczej, „Pomnik Dawnego Prawa” 2011, z. 16.

[4] Koperkiewicz A., Święci czy przeklęci? Kilka refleksji o anomaliach w pochówkach wczesnośredniowiecznych, [w:] Skóra K., Kurasiński T. (red.) Wymiary inności. Nietypowe zjawiska w obrzędowości pogrzebowej od pradziejów po czasy nowożytne, nr 56, Łódź 2010.

[5] Malinowska-Łazarczyk H., Badania woykopaliskowe na cmentarzysku w Cedyni w latach 1976-1985, „Materiały Zachodniopomorskie” 1985, t. 31.

[6] Miśkiewicz M., Wczesnośredniowieczny obrzadek pogrzebowy na ptaskich cmentarzyskach szkieletowych w Polsce, „Materiały Wczesnośredniowieczne" 1969, T. 6, 1969.

[7] Sikorski A., Atypowe groby szkieletowe z cmentarzyska w Dębczynie (stan. 53), woj. zachodniopomorskie, [w:] Wrzesiński J. (red.), Czarownice, t. 2 Wrocław-Sobótka 2000.

[8] Stanaszek Ł. M., Praktyki antywampiryczne w XI wieku stosowane na terenie cmentarzyska szkieletowego na Wzgórzu Świętojakubskim w Sandomierzu, „Biuletyn Antropologiczny" 1998, T. 2.

[9] Stanaszek Ł. M., Znaczenie cech morfofunkcjonalnych osobnika dla sposobu jego pochówku na przykładzie tzw. pochówwów antywampiryczmych, [w:] Dzieduszycki W., Wrzesiński J. (red.), Srodowisko pośmiertne człowieka, t. 9, Poznań 2007.

[10] Wojtucki D., Pochówwi skazańców na Śląsku i Łużycach w świetle nowożytnych źródeł historycznych, „Śląskie Sprawozdania Archeologiczne” 2007, T. 48 .

[11] Zoll-Adamikowa H., Wczesnośredniowieczne cmentarzyska szkieletowe Małopolski, cz. II - Analiza, Wrocław 1971.

[12] Żydok P., Wczesnośredniowieczne pochówki antywampiryczne, [w:] KobylińskiZ. (red.) Hereditatem cognoscere. Studia i szkice dedykowane prof. Marii Miśkiewicz, Warszawa 2004.

22 M. Garas, Pochówki atypowe..., dz. cyt., s. 110.

23 A. Koperkiewicz, Święci czy przeklęci..., dz. cyt., s. 76.

24 D. Wojtucki, Pochówki skazańców..., dz. cyt., s. 319.

25 A. Koperkiewicz, Świeci czy przeklęci..., dz. cyt., s. 75. 